FACTA UNIVERSITATIS

Series: Economics and Organization Vol. 13, No 4, 2016, pp. 401 - 414

DOI: 10.22190/FUEO1604401Z

Preliminary communication

\title{
BENEFIT SEGMENTATION OF OUTBOUND SUMMER PACKAGE TOURISTS
}

UDC 338.48-12

\section{Bojan Zečević, Igor Kovačević}

Faculty of Economics, University of Belgrade, Serbia

\begin{abstract}
This study assesses tourist preferences for summer package vacation benefits. The purpose of this paper is to classify summer package tourists based on preferred benefits they seek from their vacation. Analysis of preferences for benefits sought is done by using the Analytic Hierarchy Process (AHP). A sample of 850 respondents was interviewed by telephone in order to reveal their preferences. In order to reveal the grouping of tourists according to their preferred benefits, a two-step cluster analysis has been applied using the log-likelihood measure, while the number of clusters has been determined using Schwarz's Bayesian Criterion. Four segments have been identified based on the benefits sought: variety seekers, package-centrics, comfort seekers and safety seekers. This research showed that fuzzy AHP could be used not just for understanding of tourist preferences, but also as a base for segmentation. This is a first attempt to apply fuzzy AHP for that purpose in tourism.
\end{abstract}

Key words: tourist benefits, benefit segmentation, outbound package tourists

\section{INTRODUCTION}

Customer perceived value is a subjective construct (Eggert \& Ulaga, 2002; Zeithaml, 1988), defined as the perception of consumers about the difference between the benefits received from certain products and services and sacrifices that need to be invested in order to obtain and use the product or service (Zeithaml, 1988), regardless of whether value is seen as unidimensional (Cronin et al., 1997; Zeithaml, 1988) or multidimensional construct. Other group sees customer perceived value as a multidimensional construct (Mayr \& Zins, 2012; Sánchez-Garcia et al. 2007; Sinha \& DeSarbo, 1998; Sweeney \& Soutar, 2001), benefits and sacrifices are components of the value. Therefore, benefits are the essence of the perceived value (Cronin et al., 1997).

Received September 19, 2016 / Accepted November 14, 2016

Corresponding author: Bojan Zečević

Faculty of Economics, University of Belgrade, Kamenička 6, 11000 Belgrade, Serbia

E-mail: zecevic@ekof.bg.ac.rs 
In order to attract visitors, tourism destinations and service providers have to understand the needs and preferences of their customers. Knowing tourist preferences allows for the development of competitive offer and better product-market fit (J. S. Chen \& Gursoy, 2001; Kang, 2003; Pike, 2006). There are a number of research articles dealing with tourist preferences (Basala \& Klenosky, 2001; Hede \& Kellett, 2011; June \& Smith, 1987; Kim, 1996; Koo et al. 1999; Kruger \& Saayman, 2015; Lehto et al. 2004; Pike, 2006). When buying tourism products, customers are basically buying benefits. Understanding benefits tourists seek is important for destinations and business alike so they can match their offer with tourists' preferences (Woodside, 1982).

Different tourists can seek and obtain different benefits from the same product (Alford, 1998; Koh et al., 2010). Based on the importance they attach to different benefits they seek form their vacation, tourists make decisions on their travel. In this paper, Serbian summer vacation outbound tourists using services of tour operators are segmented based on preferred benefits, using fuzzy AHP.

\section{LITERATURE REVIEW}

\subsection{Benefit segmentation}

Destination and vacation attributes are causes of tourist benefits (Evans \& Chon, 1989; Goodrich, 1978; Sarigöllü \& Huang, 2005). Benefits tourists seek are an important factor of destination choice (Lang et al. 1997; Lehto et al. 2002) and also affect different tourist movement patterns within destinations (Lau \& McKercher, 2006). Understanding benefits tourists seek is important for destinations and business alike so they can match their offer with tourists' preferences (Woodside, 1982).

Benefits can be both functionally and psychologically based (Frochot \& Morrison, 2000), and refer to what is known as push and pull factors (Crompton, 1979; Dann, 1977). The first group of benefits is related to functional attributes of a vacation destination, such as nature, climate, culture and heritage, cleanliness, quality of hotels etc. The second group are socio-psychological benefits related to social interaction, strengthening family bonds, escape from everyday routine, novelty seeking etc. Socio-psychological benefits sought by tourists are result of two related processes - escape from everyday routine and intrinsic rewards tourists seek from travel activities (Iso-Ahola, 1982; Mannell \& Iso-Ahola, 1987). While psychological benefits like seeking escape from stress and everyday routine, meeting new people, spending time with family push tourists to go on a vacation in general (Crompton, 1979; Kozak, 2002), it is pull factors (trip/vacation/ destination attributes) that set the grounds for realizing those benefits (Uysal \& Jurowski, 1994).

Haley was the first to introduce the idea of benefit segmentation in 1968 (Haley, 1968). He pointed out that the knowing the benefits that consumers seek from the purchase and consumption of a product or service is the best predictor of future buying behaviour, and that the benefits are true basis for the existence of market segments (Haley, 1968, 1971), since customers differ regarding benefits they seek (Haley, 1984). The benefit based segmentation implies the analysis of what consumers think about specific product attributes, and how much importance they attach to them (Mohsen \& Dacko, 2013). Benefits sought are one of the segmentation criteria that caused great interest of researchers in tourism (Frochot, 2005; Loker \& Perdue, 1992; Palacio, 1997; 
Shoemaker, 1994). Frochot and Morrison (2000, p.24) gave a detailed overview of key studies on benefit segmentation in travel and tourism, classifying them into four broad categories of benefit segmentation application: (1) destination marketing, (2) targeting specific markets, (3) attractions, events, and facilities, and (4) examining traveller decision making process. Sarigöllü and Huang (2005) classify previous studies on benefit segmentation in terms of how benefits were obtained - through direct or indirect questioning, and by being destination specific or general. This study is based on direct questioning of tourists, and it is not destination specific.

\subsection{Tourist value chain}

The tourism industry is a complex one, which stems from the fact that the creation of tourism products are affected by many factors related to the tourist destinations and the services provided by different actors during the vacation (Gunn, 1997, p.32). A destination is an amalgam of a number of individual products and services tourists are consuming by combining them according to their needs and preferences. (Murphy et al. 2000), and value for tourists is made up of a large number of different services provided by different suppliers (Voss et al. 2008). Tourists perceive various individual services as parts of a single total experience (Räikkönen \& Honkanen, 2013), which requires linking various services provided by different actors in a unique value creation framework (Kashyap \& Bojanic, 2000).

The concept of a value chain was introduced by Porter (1985), in order to explain how different internal processes of the firm jointly contribute to the creation of customer value. Value is created not only by the firm itself but also by different companies located across different areas or even countries (Song et al. 2012). Firms can both compete and cooperate (Bendoly et al. 2004). Tourism and hospitality businesses, although many of them competing with each other, have to and can cooperate on the destination level (Leiper et al. 2011) in order to make destination more appealing to the tourists and create opportunities for better destination experience. Tourism value chain is a system of provider-customer encounter points where service is delivered (Romero \& Tejada, 2011), Yılmaz and Bititci (2006) have defined the value chain in a way that it covers all business systems involved in provision of services from the moment of the packaged vacation decision/purchase and performing necessary activities before travelling, to the return from the trip. That way the value chain is divided into four stages (p.343): Win order stage, where tourists purchase package vacation from the tour-operator. Individual tourists do not go through this stage. Pre-delivery support covers activities tourists need for the realization of the vacation before going on vacation (handling visa requirements, giving the detailed information about the vacation etc.). These two stages are supported by the activities of tour-operators and outbound travel agents. The delivery stage is where different tourism suppliers deliver their services to tourists (transportation, accommodation, transfers, excursions etc.). Post delivery support stage includes corrective measures based on the results of customer satisfaction measurement. All experiences customer has with any of the value chain members, is a part of his/her total experience delivered by the value chain (Brathwaite, 1992).Therefore, tourist benefits are realised along the value chain. 


\section{Methodology}

\subsection{Fuzzy analytic hierarchy process}

Assessment of the importance of the benefits is based on the Hierarchy Analytic Process (AHP). AHP is an analytical method that was introduced by Saaty $(1977 ; 1980)$ and is regarded as a useful multi-attribute decision making tool in determining relative importance of certain variables (Kumar et al., 2015; Mulye, 1998). AHP is a method for relative measurement, useful in situations when there is a need for making a choice among a set of alternatives based on defined criteria. Due to its inability to deal with imprecision and vaguenes of human reasoning (Wang et al. 2014), a fuzzy AHP as an extension of traditional AHP has been developed, with van Laarhoven and Pedrycz (1983) being the first to propose a fuzzy AHP with triangular fuzzy numbers. Fuzzy AHP is based on the fuzzy set theory (Zadeh, 1965). A fuzzy set is a mathematical way for the representation of uncertainty in real-life problems. Fuzzy numbers are a standard set of real numbers belonging to a limited interval of real numbers. Triangular fuzzy numbers are defined in vector form with three parameters $(1, \mathrm{~m}, \mathrm{u})$. The membership function of a triangular fuzzy number is represented in the following equation:

$$
\mu_{\tilde{A}}(x)= \begin{cases}\frac{(x-l)}{(m-l)}, & l \leq x \leq m \\ \frac{(x-u)}{(m-u)}, & m \leq x \leq u \\ 0, & \text { otherwise }\end{cases}
$$

where the parameter $m$ determines the maximal grade, while the parameters $I$ and $u$ at the lower and upper bounds. Central to fuzzy logic are linguistic variables, which are variables whose values are words or sentences in a natural or artificial language (Zadeh, 1975). In fuzzy AHP, the pairwise comparisons are performed through the linguistic variables. Linguistic variables are represented by triangular numbers (Table 1).

Table 1 Definition and membership function of fuzzy number

\begin{tabular}{lcc}
\hline Linguistic variable & Fuzzy number & Triangular fuzzy number $(1, \mathrm{~m}, \mathrm{u})$ \\
\hline Equal importance & $\tilde{1}$ & $(1,1,3)$ \\
Little importance & $\tilde{3}$ & $(1,3,5)$ \\
Strong importance & $\tilde{5}$ & $(3,5,7)$ \\
Very strong importance & $\tilde{7}$ & $(5,7,9)$ \\
Extreme importance & $\tilde{9}$ & $(7,9,9)$ \\
\hline
\end{tabular}

Implementation of fuzzy AHP involves several steps: (1) Building a hierarchy. (2) Developing pairwise fuzzy comparison matrices. (3) Testing consistency of respondents' judgments using CR ratio (Saaty, 1980). CR is calculated as a ratio between consistency index of the pairwise comparison matrix (CI) and consistency index of random matrix $(\mathrm{RI})$, where $\mathrm{CI}$, denoted $\mathrm{CI}=(\lambda \max -\mathrm{n}) /(\mathrm{n}-1)$, gives information about consistency among pairwise comparison judgments, and RI is the average value of CI obtained from 500 random positive reciprocal pairwise comparison matrices generated using the Saaty scale. If $\mathrm{CR}$ is less than $5 \%$ for a $3 \times 3$ matrix, less than $9 \%$ for a $4 \times 4$ matrix, and less than $10 \%$ for larger matrices, then the matrix is consistent (Saaty, 1995). (4) Calculating fuzzy 
weights. Using algebraic operations for fuzzy numbers (Zadeh, 1965), for each row the geometric mean $\tilde{r}_{i}=\left(\prod_{j=1}^{n} \tilde{a}_{i j}\right)^{1 / n}, i=1,2, \ldots, n$ is computed (Buckley, 1985), and then fuzzy weights for each criterion are computed by $\widetilde{w}_{i}=\tilde{r}_{i} \otimes\left(\tilde{r}_{1} \oplus \tilde{r}_{2} \oplus \ldots \oplus \tilde{r}_{n}\right)^{-1}$, where $\otimes$ and $\oplus$ represent multiplication and addition of fuzzy numbers, respectevely. (5) In order to be compared and ranked, priorities have to be defuzzified. In this study they are deffuzified by using Center of Area method. This way the Best Crisp Performance (BCP) value or Best Nonfuzzy Performance (BNP) value (Hsieh, Lu, \& Tzeng, 2004; Tzeng \& Teng, $1993)$ is calculated by $B N P_{i}=\frac{1}{3}\left[\left(u_{i}-l_{i}\right)+\left(m_{i}-l_{i}\right)\right]+l_{i}, \forall i$. (6) Crisp values have to be normalized by equation $x_{i(N O R M)}=x_{i} / \Sigma_{\mathrm{i}=1}^{\mathrm{n}} x_{i}$. (7) Local priorities obtained at different hierarchy levels are aggregated into final, global priorities.

A review of the literature revealed that AHP and fuzzy AHP have been applied in a number of tourism related studies. Crouch (2010) used AHP to determine the relative importance of different attributes of the competitiveness on the overall competitiveness of the tourist destination. AHP is used in research related to determining the relative importance of natural attractions at destinations (Deng et al. 2002), selection of a location for a theme park (Moutinho \& Curry, 1994), in convention site selection (Chen, 2006), and evaluation of hotel websites (Akincilar \& Dagdeviren, 2014). Fuzzy AHP has been applied in a selection of hotel location (Chou et al., 2008), cruise port of call selection (Wang et al., 2014) and the development of online attraction recommendation system for tourists (Huang \& Bian, 2009). Sheng-Hshiung et al. (1997) evaluated importance of travel related risks perceived by Taiwanese package tourists, and Hsu et al. (2009) used fuzzy AHP for analysing incoming tourists' preferences for destination attributes and resulting preferences for 8 tourism destinations in Taiwan. However, until now, fuzzy AHP model was not used in the analysis of the relative importance of the various benefits package tourists seek during the summer holidays, in order to reveal different market segments. To the best of our knowledge, this is the first attempt to apply fuzzy AHP for these purposes.

\subsection{Hierarchy and questionnaire design}

Benefits sought by summer vacation package tourists are broken down into the hierarchical structure according to the phases in the value chain (Fig. 1). In order to determine key benefits sought by outbound summer vacation package tourists, in-depth interviews with sales representatives of five biggest Serbian tour operators have been made, in order to determine key attributes their clients are most deeply and in detail asking about when choosing vacation package. At the end, a list of 18 most frequently sought attributes/benefits that fit into package tourist value chain has been formed. When constructing hierarchy, a value chain model developed by Yllmaz and Bititci (2006) has been adopted, with an addition of a prepurchase travel related information benefits. These are comprised of travel information search benefits related to the various information needs (Vogt \& Fesenmaier, 1998), as well as those related to the destination brand (Chang, Chen, \& Hsu, 2012). 


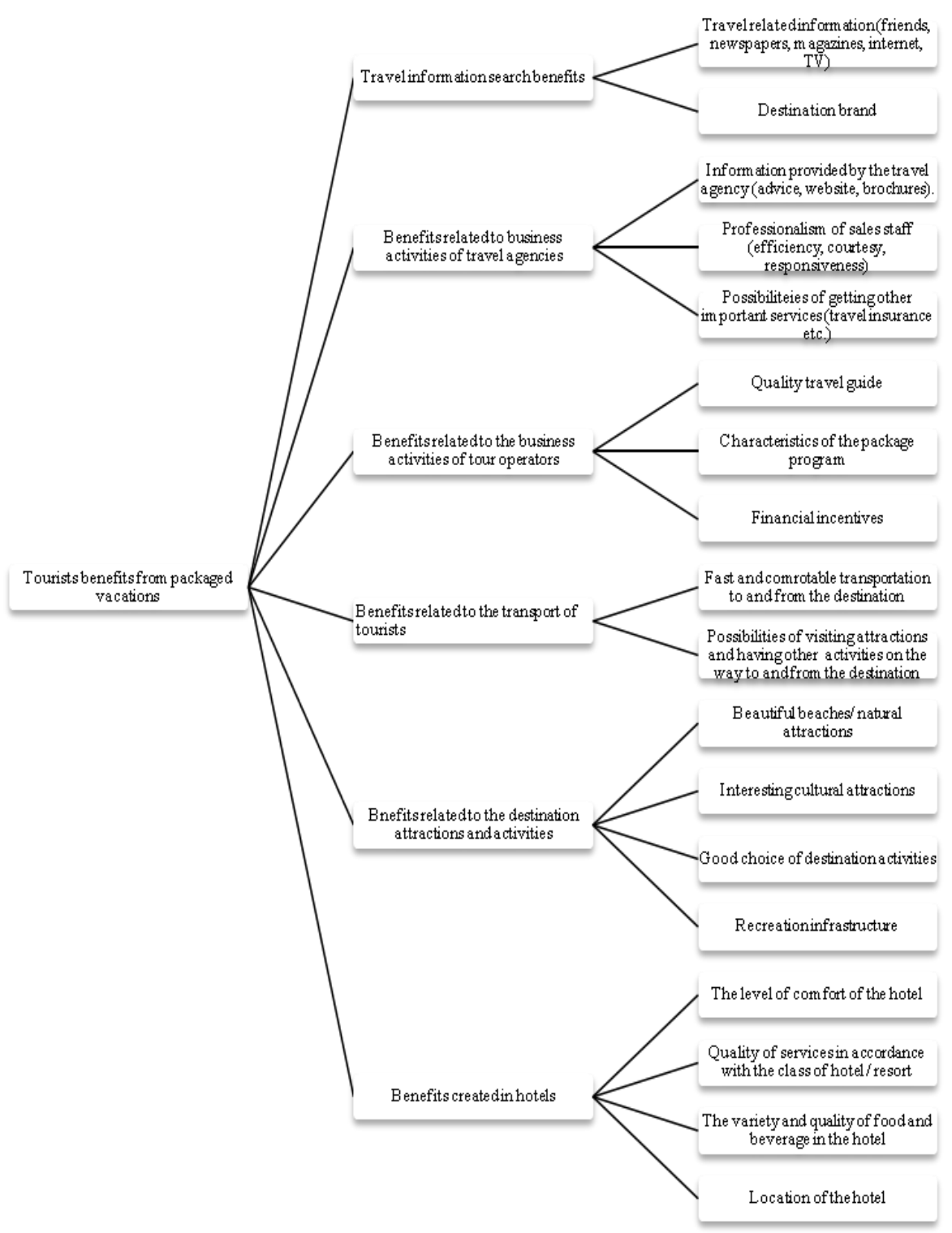

Fig. 1 Hierarchy diagram of benefits sought by summer vacation tourists

In the first part of the questionnaire the respondents were asked to answer on a fivepoint scale to what extent one variable is more important than another, using linguistic variables (Table 1). The second part of the questionnaire contained socio-demographic questions. Telephone interviewing has been used in order to get information from respondents. 


\subsection{Sample and data collection}

The survey was conducted in the Republic of Serbia on a sample of 850 respondents. The criterion of selection was the experience of travelling in the last three years within the package arrangement of tour operators. The necessity of compliance with this criterion was essential in order to be able to assess respondents' importance of different benefits they expect from the package vacation. The study used stratified sample. The criterion for defining the strata was selected based on the official statistical division of Serbia into four statistical regions - Šumadija and Western Serbia, Belgrade, Southern and Eastern Serbia, and Vojvodina. In each geographic area two largest towns were selected.

Table 2 Survey sample

\begin{tabular}{|c|c|c|c|c|c|}
\hline & & \multicolumn{2}{|c|}{ Final sample } & \multicolumn{2}{|c|}{ The original sample } \\
\hline & & $\%$ & $\mathrm{~N}=729$ & $\%$ & $\mathrm{~N}=850$ \\
\hline \multirow{2}{*}{ Sex } & Male & $37.2 \%$ & 271 & $37.1 \%$ & 297 \\
\hline & Female & $62.8 \%$ & 458 & $62.9 \%$ & 503 \\
\hline \multirow{6}{*}{ Age } & $18-24$ & $14.5 \%$ & 106 & $14.9 \%$ & 119 \\
\hline & $25-29$ & $17.8 \%$ & 130 & $17.6 \%$ & 141 \\
\hline & $30-39$ & $19.9 \%$ & 145 & $19.7 \%$ & 158 \\
\hline & $40-49$ & $19.1 \%$ & 139 & $18.5 \%$ & 148 \\
\hline & $50-59$ & $16.6 \%$ & 121 & $16.7 \%$ & 134 \\
\hline & $60+$ & $12.1 \%$ & 88 & $12.5 \%$ & 100 \\
\hline \multirow{5}{*}{$\begin{array}{l}\text { Personal } \\
\text { monthly net } \\
\text { income } \\
\text { (in Serbian } \\
\text { dinars) }\end{array}$} & No income & $23.7 \%$ & 173 & $24.2 \%$ & 194 \\
\hline & Up to 30000 & $16.5 \%$ & 120 & $17 \%$ & 136 \\
\hline & $30001-50000$ & $22.5 \%$ & 164 & $21.4 \%$ & 171 \\
\hline & Over 50000 & $14.7 \%$ & 107 & $14.7 \%$ & 118 \\
\hline & Doesn't know/refuses to answer & $22.6 \%$ & 165 & $22.6 \%$ & 181 \\
\hline \multirow{5}{*}{$\begin{array}{l}\text { Monthly } \\
\text { household net } \\
\text { income per } \\
\text { person } \\
\text { (in Serbian } \\
\text { dinars) }\end{array}$} & Up to 20000 & $17.8 \%$ & 130 & $18.5 \%$ & 148 \\
\hline & $20001-30000$ & $16.6 \%$ & 121 & $15.7 \%$ & 126 \\
\hline & $30001-50000$ & $18.8 \%$ & 137 & $18.5 \%$ & 148 \\
\hline & Over 50000 & $11.8 \%$ & 86 & $12.1 \%$ & 97 \\
\hline & Doesn't know/refuses to answer & $35.0 \%$ & 255 & $35.1 \%$ & 281 \\
\hline \multirow{4}{*}{$\begin{array}{l}\text { Place of } \\
\text { residence }\end{array}$} & Belgrade & $23.9 \%$ & 172 & $23.64 \%$ & 187 \\
\hline & Šumadija and Western Serbia & $28.9 \%$ & 208 & $29.3 \%$ & 232 \\
\hline & Southern and Eastern Serbia & $25.8 \%$ & 186 & $25.8 \%$ & 204 \\
\hline & Vojvodina & $21.4 \%$ & 154 & $21.2 \%$ & 168 \\
\hline \multirow{4}{*}{ Education } & $\begin{array}{l}\text { Incomplete primary / primary / } \\
3 \text { years secondary school }\end{array}$ & $7.4 \%$ & 54 & $8.1 \%$ & 65 \\
\hline & 4 years secondary school & $41.3 \%$ & 301 & $41 \%$ & 328 \\
\hline & College & $15.2 \%$ & 111 & $16 \%$ & 128 \\
\hline & University diploma & $36.1 \%$ & 263 & $34.9 \%$ & 279 \\
\hline
\end{tabular}


The survey was conducted by telephone. Contacts have been chosen randomly from the Telekom Serbia database. On average, every twentieth contact was eligible for the survey. Reasons for ineligibility were: (1) not answering the phone; (2) refusal to participate in the survey; (3) unfulfilled criteria regarding previous package vacation experiences, and (4) not fitting in the necessary demographic profile.

\section{RESULTS AND DISCUSSION}

Based on answers from respondents, a fuzzy comparison matrix has been formed. Based on Saaty's threshold (Saaty, 1995), respondents whose comparisons were inconsistent, were excluded from the further analysis. It was found that there were 121 respondents with 189 inconsistent responses. Following the fuzzy AHP procedure, the overall ranking of the benefits summer package tourists seek, has been obtained based on their importance (Table 3).

In order to reveal the grouping of tourists according to their preferred benefits, a twostep cluster analysis has been applied using the log-likelihood measure (Chiu et al., 2001; Zhang et al., 1996). The number of clusters have been determined using Schwarz's Bayesian Criterion (BIC). With four clasters, BIC has the lowest value $(901,323)$ and the change in BIC between adjacent number of clusters is smallest $(0,293)$, while the ratio of distance measure is the biggest $(1,412)$.

Table 4 shows the importance of benefits for each of the four segments identified. It is obvious that segments differ in preferred benefits they seek. Moreover, there is no overlapping between segments in first 4 most preferred benefits

The first segment (variety seekers) is comprised of tourists who prefer benefits emanating from destination attractions and activities. Benefits they seek are related to natural resources (beautiful beaches and natural attractions), a rich cultural heritage, good choice of quality destination activities and recreation infrastructure. In other words, this segment seeks the diversity of destination experiences. Also, this segment finds availability of information about the destination from different sources (TV, magazines, internet, friends etc.) very beneficial.

The second segment (package-centrics) is made of tourists whose benefits sought center around activities of tour operators and travel agencies. Characteristics of the tour program, the provision of tour leading/guiding services as well as the existence of financial incentives are essential to them, followed by the possibilities of visiting attractions and having other activities on the way to and from the destination, and quick and comfortable transportation to and from the destination. This segment represents the typical mass tourist, without interest for a deeper exploration of the destination.

The third segment are comfort seekers whose most important benefits are those created in hotels - the variety and quality of hotel food and beverages, the quality of services in accordance with the class of hotel / resort, the level of comfort of the hotel, the location of the hotel. In addition to the services provided in hotels, significant benefits are related to the transport services that facilitate travel - quick and comfortable transportation to and from the destination. This segment, in essence, prefers maximum comfort on holiday. 
Table 3 Overall ranking of the importance of benefits

\begin{tabular}{|c|c|c|c|c|c|c|}
\hline $\begin{array}{c}\text { Goa } \\
1 \\
\end{array}$ & Level 1 (Criteria) & Weight & Level 2 (subcriteria) & Weight & $\begin{array}{l}\text { Global } \\
\text { weight }\end{array}$ & Rank \\
\hline \multirow{18}{*}{ 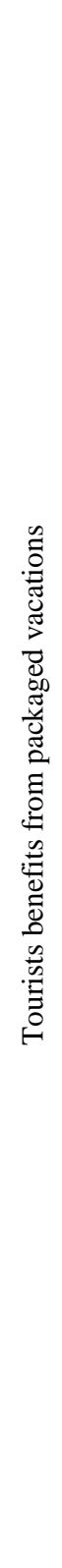 } & $\begin{array}{l}\text { Benefits from } \\
\text { travel related } \\
\text { information }\end{array}$ & \multirow[t]{2}{*}{0,115} & $\begin{array}{l}\text { Information search benefits } \\
\text { (information from friends, } \\
\text { newspapers, magazines, internet, TV) }\end{array}$ & 0,516 & 0,059 & 7 \\
\hline & $\begin{array}{l}\text { C. } I .=0.093, \\
\text { C. } R .=0.010\end{array}$ & & Destination brand & 0,484 & 0,056 & 8 \\
\hline & \multirow{3}{*}{$\begin{array}{l}\text { Benefits that are } \\
\text { created through } \\
\text { the business } \\
\text { activities of } \\
\text { travel agencies }\end{array}$} & \multirow{3}{*}{0,131} & $\begin{array}{l}\text { The information provided by the } \\
\text { travel agency } \\
\text { (advice, website, brochures) }\end{array}$ & 0,307 & 0,040 & 17 \\
\hline & & & $\begin{array}{l}\text { The professionalism of sales staff } \\
\text { (efficiency, courtesy, responsiveness) }\end{array}$ & 0,361 & 0,047 & 15 \\
\hline & & & $\begin{array}{l}\text { Possibilities of getting other } \\
\text { important services (reservations, } \\
\text { travel insurance etc.). }\end{array}$ & 0,331 & 0,043 & 16 \\
\hline & \multirow{2}{*}{$\begin{array}{l}\text { Benefits related } \\
\text { to the business } \\
\text { activities of tour } \\
\text { operators }\end{array}$} & \multirow{3}{*}{0,185} & Quality travel guide & 0,291 & 0,054 & 10 \\
\hline & & & $\begin{array}{l}\text { The characteristics of the package } \\
\text { program }\end{array}$ & 0,353 & 0,065 & 3 \\
\hline & $\begin{array}{l}\text { C.I. }=0.0129, \\
\text { C.R. }=0.014\end{array}$ & & $\begin{array}{l}\text { Financial incentives for the purchase } \\
\text { of the package }\end{array}$ & 0,354 & 0,066 & 2 \\
\hline & \multirow{2}{*}{$\begin{array}{l}\text { Benefits related } \\
\text { to the transport } \\
\text { of tourists }\end{array}$} & \multirow[b]{2}{*}{0,102} & $\begin{array}{l}\text { Quick and comfortable transportation } \\
\text { to and from the destination }\end{array}$ & 0,492 & 0,052 & 12 \\
\hline & & & $\begin{array}{l}\text { The possibility of visiting attractions } \\
\text { and having other activities during the } \\
\text { trip }\end{array}$ & 0,508 & 0,050 & 13 \\
\hline & \multirow{3}{*}{$\begin{array}{l}\text { Benefits related } \\
\text { to the destination } \\
\text { attractions and } \\
\text { activities }\end{array}$} & \multirow{4}{*}{0,245} & Beautiful beaches/natural attractions & 0,256 & 0,063 & 6 \\
\hline & & & Interesting cultural attractions & 0,264 & 0,067 & 1 \\
\hline & & & Good choice of destination activities & 0,259 & 0,064 & 5 \\
\hline & \multirow[t]{2}{*}{$\begin{array}{l}\text { C. } I .=0.089, \\
\text { C.R. }=0.015\end{array}$} & & Recreation infrastructure & 0,221 & 0,053 & 11 \\
\hline & & \multirow{4}{*}{0,222} & The level of comfort of the hotel & 0,250 & 0,057 & 7 \\
\hline & $\begin{array}{l}\text { Benefits created } \\
\text { in hotels }\end{array}$ & & $\begin{array}{l}\text { Quality of services in accordance with } \\
\text { the class of hotel / resort }\end{array}$ & 0,219 & 0,049 & 14 \\
\hline & \multirow[t]{2}{*}{$\begin{array}{l}\text { C.I. }=0.036, \\
\text { C.R. }=0.032\end{array}$} & & $\begin{array}{l}\text { The variety and quality of food and } \\
\text { beverages in the hotel }\end{array}$ & 0,287 & 0,065 & 4 \\
\hline & & & The location of the hotel & 0,244 & 0,054 & 9 \\
\hline
\end{tabular}


Table 4 Ranking of benefits sought by segments of outbound summer vacation tourists

\begin{tabular}{|c|c|c|c|c|}
\hline Benefits & $\begin{array}{c}\text { Segment } 1 \\
\text { Variety } \\
\text { seekers } \\
(\mathrm{N}=167, \\
22.9 \%) \\
\end{array}$ & $\begin{array}{c}\begin{array}{c}\text { Segment } 2 \\
\text { Package- } \\
\text { centrics } \\
(\mathrm{N}=154 \\
21.1 \%)\end{array} \\
\end{array}$ & $\begin{array}{c}\text { Segment } 3 \\
\text { Comfort } \\
\text { seekers } \\
(\mathrm{N}=145, \\
19.9 \%)\end{array}$ & $\begin{array}{c}\text { Segment } 4 \\
\text { Safety } \\
\text { seekers } \\
(\mathrm{N}=263, \\
36.1 \%) \\
\end{array}$ \\
\hline Information search benefits & 5 & 18 & 18 & 1 \\
\hline Destination brand & 7 & 15 & 17 & 2 \\
\hline $\begin{array}{l}\text { The information provided by the travel agency } \\
\text { (advice, website, brochures) }\end{array}$ & 12 & 11 & 16 & 3 \\
\hline $\begin{array}{l}\text { The professionalism of sales staff (efficiency, } \\
\text { courtesy, responsiveness) }\end{array}$ & 13 & 9 & 14 & 5 \\
\hline $\begin{array}{l}\text { Possibilities of getting other important services } \\
\text { (reservations, travel insurance etc.). }\end{array}$ & 11 & 12 & 15 & 4 \\
\hline Quality travel guide & 16 & 2 & 7 & 8 \\
\hline The characteristics of the package program & 8 & 1 & 9 & 6 \\
\hline Financial incentives for the purchase of the package & 10 & 3 & 10 & 7 \\
\hline $\begin{array}{l}\text { Quick and comfortable transportation to and from the } \\
\text { destination }\end{array}$ & 15 & 5 & 3 & 12 \\
\hline $\begin{array}{l}\text { The possibility of visiting attractions and having } \\
\text { other activities on the way to and from the destination }\end{array}$ & 14 & 4 & 6 & 10 \\
\hline Beautiful beaches/natural attractions & 4 & 13 & 8 & 11 \\
\hline Interesting cultural attractions & 1 & 14 & 11 & 15 \\
\hline Good choice of destination activities & 2 & 17 & 13 & 9 \\
\hline Recreation infrastructure & 3 & 16 & 12 & 16 \\
\hline The level of comfort of the hotel & 18 & 10 & 5 & 18 \\
\hline $\begin{array}{l}\text { Quality of services in accordance with the class of } \\
\text { hotel / resort }\end{array}$ & 17 & 8 & 2 & 17 \\
\hline $\begin{array}{l}\text { The variety and quality of food and beverages in the } \\
\text { hotel }\end{array}$ & 9 & 6 & 1 & 14 \\
\hline The location of the hotel & 6 & 7 & 4 & 13 \\
\hline
\end{tabular}

The fourth segment (safety seekers) are those to whom safety and risk mitigation are substantial. They highly value destination brand and all he pre-trip information they can get before going to buy the package vacation. In this respect, they also prefer the benefits that are created through the provision of services by travel agencies, and advisory services by their sales staff. They also look for getting other important services for a hassle-free vacation, like travel insurance.

\section{CONCLUSION}

This research showed that fuzzy AHP could be used not just for understanding of tourist preferences, but also as a base for a segmentation. This is a first attempt to apply fuzzy AHP for that purpose in tourism.

This study has shown that, as Frochot \& Morrison (2000) argued, benefit segmentation could be used for development or modifying of vacation packages, and is in line with previous studies (Calantone \& Johar, 1984; Woodside \& Jacobs, 1985). Also, segmentation 
based on benefits tourists seek could help destinations coordinate activities of actors along the destination value chain, as well as to create more efficient marketing campaigns.

There are some limitations of this research, which has set the basis for future research. The choice of benefits included into AHP model is made based on deep interviews with tour operators' sales representatives. Although they are in contact with tourists and can comprehend their preferences, wishes and benefits sought, still the best way to reveal tourist benefits is to ask them directly (Chacko, 1996). Consequently, benefits and this research are related only to the pull factors. Without asking tourists, it was not possible to reveal push factors. Also, various financial, time or risk constraints were not taken into consideration (Tian, Crompton, \& Witt, 1996). The study refers to the Serbian outbound summer vacation package market, and results could not be generalized.

\section{REFERENCES}

Akincilar, A., \& Dagdeviren, M. (2014). A hybrid multi-criteria decision making model to evaluate hotel websites. International Journal of Hospitality Management, 36, 263-271. http://doi.org/10.1016/j.ijhm. 2013.10.002

Alford, P. (1998). Positioning the Destination Product-Can Regional Tourist Boards Learn from Private Sector Practice? Journal of Travel \& Tourism Marketing, 7(2), 53-68. http://doi.org/10.1300/J073v07n02_03

Basala, S. L., \& Klenosky, D. B. (2001). Travel-Style Preferences for Visiting a Novel Destination: A Conjoint Investigation across the Novelty-Familiarity Continuum. Journal of Travel Research, 40(2), 172-182. http://doi.org/10.1177/004728750104000208

Bendoly, E., Soni, A., \& Venkataramanan, M. A. (2004). Value chain resource planning: Adding value with systems beyond the enterprise. Business Horizons, 47(2), 79-86. http://doi.org/10.1016/j.bushor.2003. 08.004

Brathwaite, R. (1992). Value-chain assessment of the travel experience. The Cornell Hotel and Restaurant Administration Quarterly, 33(5), 41-49. http://doi.org/10.1016/0010-8804(92)90026-2

Buckley, J. J. (1985). Fuzzy hierarchical analysis. Fuzzy Sets and Systems, 17(3), 233-247. http://doi.org/10.1016/ 0165-0114(85)90090-9

Calantone, R. J., \& Johar, J. S. (1984). Seasonal Segmentation of the Tourism Market Using a Benefit Segmentation Framework. Journal of Travel Research, 23(2), 14-24. http://doi.org/10.1177/004728758402300203

Chacko, H. E. (1996). Positioning a tourism destination to gain a competitive edge. Asia Pacific Journal of Tourism Research, 1(2), 69-75. http://doi.org/10.1080/10941669708721976

Chang, K.-C., Chen, M.-C., \& Hsu, C.-L. (2012). Identifying Critical Brand Contact Elements of a Tourist Destination: Applications of Kano's Model and the Importance-satisfaction Model. International Journal of Tourism Research, 14(3), 205-221. http://doi.org/10.1002/jtr.839

Chen, C.-F. (2006). Applying the Analytical Hierarchy Process (AHP) Approach to Convention Site Selection. Journal of Travel Research, 45(2), 167-174. http://doi.org/10.1177/0047287506291593

Chen, J. S., \& Gursoy, D. (2001). An investigation of tourists' destination loyalty and preferences. International Journal of Contemporary Hospitality Management, 13(2), 79-85. http://doi.org/10.1108/09596110110381870

Chiu, T., Fang, D., Chen, J., Wang, Y., \& Jeris, C. (2001). A robust and scalable clustering algorithm for mixed type attributes in large database environment. In Proceedings of the seventh ACM SIGKDD international conference on knowledge discovery and data mining (pp. 263-268). New York: ACM.

Chou, T.-Y., Hsu, C.-L., \& Chen, M.-C. (2008). A fuzzy multi-criteria decision model for international tourist hotels location selection. International Journal of Hospitality Management, 27(2), $293-301$. http://doi.org/10.1016/j.ijhm.2007.07.029

Crompton, J. L. (1979). Motivations for pleasure vacation. Annals of Tourism Research, 6(4), 408-424. http://doi.org/10.1016/0160-7383(79)90004-5

Cronin, J. J., Brady, M. K., Brand, R. R., Hightower Jr, R., \& Shemwell, D. J. (1997). A cross-sectional test of the effect and conceptualization of service value. Journal of Services Marketing, 11(6), 375-391. Retrieved from http://www.emeraldinsight.com/doi/abs/10.1108/08876049710187482

Crouch, G. I. (2010). Destination Competitiveness: An Analysis of Determinant Attributes. Journal of Travel Research, 50(1), 27-45. http://doi.org/10.1177/0047287510362776 
Dann, G. M. S. (1977). Anomie, ego-enhancement and tourism. Annals of Tourism Research, 4(4), $184-194$. http://doi.org/10.1016/0160-7383(77)90037-8

Deng, J., King, B., \& Bauer, T. (2002). Evaluating natural attractions for tourism. Annals of Tourism Research, 29(2), 422-438. http://doi.org/10.1016/S0160-7383(01)00068-8

Eggert, A., \& Ulaga, W. (2002). Customer perceived value: a substitute for satisfaction in business markets? Journal of Business \& Industrial Marketing, 17(2/3), 107-118. http://doi.org/10.1108/08858620210419754

Evans, M. R., \& Chon, K.-S. (1989). Formulating and Evaluating Tourism Policy Using Importance-Performance Analysis. Journal of Hospitality \& Tourism Research, 13(3), 203-213. http://doi.org/10.1177/109634808901300320

Frochot, I. (2005). A benefit segmentation of tourists in rural areas: a Scottish perspective. Tourism Management, 26(3), 335-346. http://doi.org/10.1016/j.tourman.2003.11.016

Frochot, I., \& Morrison, A. M. (2000). Benefit Segmentation: A Review of Its Applications to Travel and Tourism Research. Journal of Travel \& Tourism Marketing, 9(4), 21-45. http://doi.org/10.1300/J073v09n04 02

Goodrich, J. N. (1978). The Relationship Between Preferences for and Perceptions of Vacation Destinations: Application of a Choice Model. Journal of Travel Research, 17(2), 8-13. http://doi.org/10.1177/ 004728757801700202

Gunn, C. A. (1997). Vacationscape: Developing Tourist Areas. Washington DC: Taylor \& Francis.

Haley, R. I. (1968). Benefit Segmentation: A Decision-Oriented Research Tool. Journal of Marketing, 32(3), 30-35. http://doi.org/10.2307/1249759

Haley, R. I. (1971). Beyond Benefit Segmentation. Journal of Advertising Research, 11., 3-8.

Haley, R. I. (1984). Benefit Segmentation - 20 Years Later. Journal of Consumer Marketing, 1(2), 5-13. http://doi.org/10.1108/eb008090

Hede, A.-M., \& Kellett, P. (2011). Marketing communications for special events: Analysing managerial practice, consumer perceptions and preferences. European Journal of Marketing, 45(6), 987-1004. http://doi.org/10.1108/03090561111119930

Hsieh, T.-Y., Lu, S.-T., \& Tzeng, G.-H. (2004). Fuzzy MCDM approach for planning and design tenders selection in public office buildings. International Journal of Project Management, 22(7), 573-584. http://doi.org/10.1016/j.ijproman.2004.01.002

Hsu, T.-K., Tsai, Y.-F., \& Wu, H.-H. (2009). The preference analysis for tourist choice of destination: A case study of Taiwan. Tourism Management, 30(2), 288-297. http://doi.org/10.1016/j.tourman.2008.07.011

Huang, Y., \& Bian, L. (2009). A Bayesian network and analytic hierarchy process based personalized recommendations for tourist attractions over the Internet. Expert Systems with Applications, 36(1), 933943. http://doi.org/10.1016/j.eswa.2007.10.019

Iso-Ahola, S. E. (1982). Toward a social psychological theory of tourism motivation: A rejoinder. Annals of Tourism Research, 9(2), 256-262. http://doi.org/10.1016/0160-7383(82)90049-4

June, L. P., \& Smith, S. L. J. (1987). Service Attributes And Situational Effects On Customer Preferences For Restaurant Dining. Journal of Travel Research, 26(2), 20-27. http://doi.org/10.1177/004728758702600205

Kang, S. K. (2003). Family Traveler Segmentation by Vacation Decision-Making Patterns. Journal of Hospitality \& Tourism Research, 27(4), 448-469. http://doi.org/10.1177/10963480030274005

Kashyap, R., \& Bojanic, D. C. (2000). A Structural Analysis of Value, Quality, and Price Perceptions of Business and Leisure Travelers. Journal of Travel Research, 39(1), 45-51. http://doi.org/10.1177/ 004728750003900106

Kim, H. (1996). Perceptual mapping of attributes and preferences: an empirical examination of hotel F\&B products in Korea. International Journal of Hospitality Management, 15(4), 373-391. http://doi.org/10.1016/S0278-4319(96)00040-0

Koh, S., Jung-Eun Yoo, J., \& Boger, C. A. (2010). Importance-performance analysis with benefit segmentation of spa goers. International Journal of Contemporary Hospitality Management, 22(5), 718-735. http://doi.org/10.1108/09596111011053828

Koo, L. C., Tao, F. K. C., \& Yeung, J. H. . (1999). Preferential segmentation of restaurant attributes through conjoint analysis. International Journal of Contemporary Hospitality Management, 11(5), $242-253$. http://doi.org/10.1108/09596119910272784

Kozak, M. (2002). Comparative analysis of tourist motivations by nationality and destinations. Tourism Management, 23(3), 221-232. http://doi.org/10.1016/S0261-5177(01)00090-5

Kruger, M., \& Saayman, M. (2015). Consumer preferences of Generation Y: Evidence from live music tourism event performances in South Africa. Journal of Vacation Marketing, 21(4), 366-382. http://doi.org/ $10.1177 / 1356766715585903$

Kumar, A., Shankar, R., \& Debnath, R. M. (2015). Analyzing customer preference and measuring relative efficiency in telecom sector: A hybrid fuzzy AHP/DEA study. Telematics and Informatics, 32(3), 447-462. http://doi.org/10.1016/j.tele.2014.10.003 
Lang, C.-T., O’Leary, J. T., \& Morrison, A. M. (1997). Distinguishing the Destination Choices of Pleasure Travelers from Taiwan. Journal of Travel \& Tourism Marketing, 6(1), 21-40. http://doi.org/10.1300/ J073v06n01_03

Lau, G., \& McKercher, B. (2006). Understanding tourist movement patterns in a destination: A GIS approach. Tourism and Hospitality Research, 7(1), 39-49. http://doi.org/10.1057/palgrave.thr.6050027

Lehto, X. Y., Cai, L. A., O’Leary, J. T., \& Huan, T.-C. (2004). Tourist shopping preferences and expenditure behaviours: The case of the Taiwanese outbound market. Journal of Vacation Marketing, 10(4), 320-332. http://doi.org/10.1177/135676670401000404

Lehto, X. Y., O’Leary, J. T., \& Morrison, A. M. (2002). Do psychographics influence vacation destination choices? A comparison of British travellers to North America, Asia and Oceania. Journal Of Vacation Marketing, 8(2), 109-125. http://doi.org/10.1177/135676670200800202

Leiper, N., Lamont, M., \& Hing, N. (2011). Cooperative Business Organizations: Intrinsic in Every Strategically Functional Tourism Industry. Tourism Culture \& Communication, 11(1), 57-67. http://doi.org/10.3727/ 109830411 X13049571092769

Loker, L. E., \& Perdue, R. R. (1992). A Benefit-based Segmentation of a Nonresident Summer Travel Market. Journal of Travel Research, 31(1), 30-35. http://doi.org/10.1177/004728759203100107

Mannell, R. C., \& Iso-Ahola, S. E. (1987). Psychological nature of leisure and tourism experience. Annals of Tourism Research, 14(3), 314-331. http://doi.org/10.1016/0160-7383(87)90105-8

Mayr, T., \& Zins, A. H. (2012). Extensions on the conceptualization of customer perceived value: insights from the airline industry. International Journal of Culture, Tourism and Hospitality Research, 6(4), 356-376. http://doi.org/10.1108/17506181211265086

Mohsen, M. G., \& Dacko, S. (2013). An extension of the benefit segmentation base for the consumption of organic foods: A time perspective. Journal of Marketing Management, 29(15-16), 1701-1728. http://doi.org/10.1080/0267257X.2013.800896

Moutinho, L., \& Curry, B. (1994). Modelling Site Location Decisions in Tourism. Journal of Travel \& Tourism Marketing, 3(2), 35-57. http://doi.org/10.1300/J073v03n02_03

Mulye, R. (1998). An empirical comparison of three variants of the AHP and two variants of conjoint analysis. Journal of Behavioral Decision Making, 11(4), 263-280. http://doi.org/10.1002/(SICI)10990771(1998120)11:4<263::AID-BDM301>3.0.CO;2-T

Murphy, P., Pritchard, M. P., \& Smith, B. (2000). The destination product and its impact on traveller perceptions. Tourism Management, 21(1), 43-52. http://doi.org/10.1016/S0261-5177(99)00080-1

Palacio, V. (1997). Identifying Ecotourists in Belize Through Benefit Segmentation: A Preliminary Analysis. Journal of Sustainable Tourism, 5(3), 234-243. http://doi.org/10.1080/09669589708667288

Pike, S. (2006). Destination decision sets: A longitudinal comparison of stated destination preferences and actual travel. Journal of Vacation Marketing, 12(4), 319-328. http://doi.org/10.1177/1356766706067604

Räikkönen, J., \& Honkanen, A. (2013). Does satisfaction with package tours lead to successful vacation experiences? Journal of Destination Marketing \& Management, 2(2), 108-117. http://doi.org/10.1016/ j.jdmm.2013.03.002

Romero, I., \& Tejada, P. (2011). A multi-level approach to the study of production chains in the tourism sector. Tourism Management, 32(2), 297-306. http://doi.org/10.1016/j.tourman.2010.02.006

Saaty, T. L. (1977). A scaling method for priorities in hierarchical structures. Journal of Mathematical Psychology, 15(3), 234-281. http://doi.org/10.1016/0022-2496(77)90033-5

Saaty, T. L. (1980). The Analytic Hierarchy Process. (B. L. Golden, E. A. Wasil, \& P. T. Harker, Eds.). Berlin, Heidelberg: McGraw-Hill. http://doi.org/10.1007/978-3-642-50244-6

Saaty, T. L. (1995). Decision Making for Leaders (3rd ed.). Pittsburgh: RWS Publications

Sánchez-Garcia, J., Moliner-Tena, M. A., Callarisa-Fiol, L., \& Rodríguez-Artola, R. M. (2007). Relationship Quality of an Establishment and Perceived Value of a Purchase. The Service Industries Journal, 27(2), 151-174. http://doi.org/10.1080/02642060601122710

Sarigöllü, E., \& Huang, R. (2005). Benefits Segmentation of Visitors to Latin America. Journal of Travel Research, 43(3), 277-293. http://doi.org/10.1177/0047287504272032

Sheng-Hshiung, T., Gwo-Hshiung, T., \& Kuo-Ching, W. (1997). Evaluating tourist risks from fuzzy perspectives. Annals of Tourism Research, 24(4), 796-812. http://doi.org/10.1016/S0160-7383(97)00059-5

Shoemaker, S. (1994). Segmenting the U.S. Travel Market According to Benefits Realized. Journal of Travel Research, 32(3), 8-21. http://doi.org/10.1177/004728759403200303

Sinha, N., \& DeSarbo, W. S. (1998). An Integrated Approach toward the Spatial Modeling of Perceived Customer Value. Journal of Marketing Research, 35(2), 236-249. DOI: 10.2307/3151851

Song, H., Liu, J., \& Chen, G. (2012). Tourism Value Chain Governance: Review and Prospects. Journal of Travel Research, 52(1), 15-28. http://doi.org/10.1177/0047287512457264 
Sweeney, J. C., \& Soutar, G. N. (2001). Consumer perceived value: The development of a multiple item scale. Journal of Retailing, 77(2), 203-220. http://doi.org/10.1016/S0022-4359(01)00041-0

Tian, S., Crompton, J. L., \& Witt, P. A. (1996). Integrating Constraints and Benefits to Identify Responsive Target Markets for Museum Attractions. Journal of Travel Research, 35(2), 34-45. http://doi.org/ $10.1177 / 004728759603500207$

Tzeng, G., \& Teng, J. (1993). Transportation investment project selection with fuzzy multiobjectives, 17(2), 91-112. http://doi.org/10.1080/03081069308717504

Uysal, M., \& Jurowski, C. (1994). Testing the push and pull factors. Annals of Tourism Research, 21(4), 844846. http://doi.org/10.1016/0160-7383(94)90091-4

van Laarhoven, P. J. M., \& Pedrycz, W. (1983). A fuzzy extension of Saaty's priority theory. Fuzzy Sets and Systems, 11(1-3), 229-241. http://doi.org/doi:10.1016/S0165-0114(83)80082-7

Vogt, C. A., \& Fesenmaier, D. R. (1998). Expanding the functional information search model. Annals of Tourism Research, 25(3), 551-578. http://doi.org/10.1016/S0160-7383(98)00010-3

Voss, C., Roth, A. V., \& Chase, R. B. (2008). Experience, Service Operations Strategy, and Services as Destinations: Foundations and Exploratory Investigation. Production and Operations Management, 17(3), 247-266. http://doi.org/10.3401/poms.1080.0030

Wang, Y., Jung, K.-A., Yeo, G.-T., \& Chou, C.-C. (2014). Selecting a cruise port of call location using the fuzzy-AHP method: A case study in East Asia. Tourism Management, 42, 262-270. http://doi.org/10.1016/ j.tourman.2013.11.005

Woodside, A. G. (1982). Positioning a Province Using Travel Research. Journal of Travel Research, 20(3), 26. http://doi.org/10.1177/004728758202000301

Woodside, A. G., \& Jacobs, L. W. (1985). Step Two in Benefit Segmentation: Learning the Benefits Realized by Major Travel Markets. Journal of Travel Research, 24(1), 7-13. http://doi.org/10.1177/004728758502400102

Yilmaz, Y., \& Bititci, U. S. (2006). Performance measurement in tourism: a value chain model. International Journal of Contemporary Hospitality Management, 18(4), 341-349. http://doi.org/10.1108/09596110610665348

Zadeh, L. A. (1965). Fuzzy sets. Information and Control, 8(3), 338-353. http://doi.org/10.1016/S00199958(65)90241-X

Zadeh, L. A. (1975). The concept of a linguistic variable and its application to approximate reasoning-II. Information Sciences, 8(4), 301-357. http://doi.org/10.1016/0020-0255(75)90046-8

Zeithaml, V. A. (1988). Consumer Perceptions of Price, Quality, and Value: A Means-End Model and Synthesis of Evidence. Journal of Marketing, 52(3), 2-22. DOI: 10.2307/1251446

Zhang, T., Ramakrishnan, R., \& Livny, M. (1996). BIRCH: an efficient data clustering method for very large databases. In ACM Sigmod Record, vol. 25, no. 2 (pp. 103-114). New York: ACM. http://doi.org/ $10.1145 / 235968.233324$

\section{SEGMENTACIJA TURISTA KOJI KORISTE LETNJE PAKET ARANŽMANE ZA INOSTRANSTVO NA OSNOVU KORISTI}

Ova studija daje analizu preferencija turista za koristima proisteklim iz letnjih odmora putem paket aranžmana. Svrha rada je da klasifikuje turist koji putuju na letnje odmore korišćenjem paket aranžmana, na temelju preferiranih koristi koje traže od svog putovanja. Analiza preferiranih traženih koristi je urađena korišćenjem analitlčkog hijerarhijskog procesa (AHP). Uzorak od 850 ispitanika je intervjuiran putem telefona kako bi se otkrille njihove preferencije. Da bi se utvrdilo kako se turisti grupišu u segmente prema preferiranim koristima, primenjena je dvostepena klaster analiza korišćenjem mere funkcije verodostojnosti, a broj klastera je utvrdjen korišćenjem ŠvarcBajezovog kriterijuma. Identifikovana su četiri segmenta po osnovu traženih koristi: oni koji traže raznovrsnost, oni koji traže koristi fokusirane na sam paket, oni koji traže komfor i oni koji preferiraju sigurnost. Ovo istraživanje je pokazalo da se fazi AHP može koristiti ne samo za razumevanje preferencija turista, nego i kao osnov za segmentaciju. Ovo je prvi pokušaj primene fazi AHP za tu namenu и turizmu.

Ključne reči: koristi za turiste, segmentacija po osnovu koristi, turisti koji koriste letnje paket aranžmane 